\title{
SYMPOSIUM ON THE INTERNATIONAL LEGAL OBLIGATION TO CRIMINALIZE MARITAL RAPE
}

\author{
MARITAL RAPE: \\ THE LONG ARCH OF SEXUAL VIOLENCE AGAINST WOMEN AND GIRLS
}

Michele Goodwin*

If no permanent injury has been inflicted, nor malice, cruelty nor dangerous violence shown by the busband, it is better to draw the curtain, shut out the public gaze, and leave the parties to forget and forgive.

State v. Oliver, 70 N.C. 60,62 (1874)

\section{Prologue: The Context}

Sadly, sexual violence against women and girls remains deeply entrenched and politicized around the globe. Perhaps no other allegation of crime exposes a woman's credibility to such intense hostility and imposes the penalties of shame and stigma to a more severe degree than alleging rape. Factors irrelevant to sexual violence, including the victim's choice of clothing, hairstyle, and time of the attack frequently serve as points of searching inquiry, and scrutiny. Such extraneous points of critique further compound an atmosphere of shaming and stigmatization associated with sexual violence, but are seen as crucial in bolstering an affirmative defense and inevitably building the case against rape victims.

For example, in Delhi, India, after the notorious gang rape of a female medical student, which resulted in the young woman's death, some politicians blamed the victim. Such political attacks against rape victims further legitimize defendants' claims that women should not be out at night. In that case, one of the defendants urged his innocence by explaining, "you can't clap with one hand . . . it takes two hands. A decent girl won't roam around at 9 o'clock at night." Ashe Mirje, a prominent leader in India's Nationalist Congress Party who serves on India's women's commission, reiterated these sentiments when she claimed, "[r]apes take place also because of a woman's clothes, her behavior and her presence at inappropriate places." 2 She asked, did the twenty-three-year-old victim "really have to go watch a movie at 11 in the night with her friend?"3 And India is not alone in its contempt for rape victims.

In Afghanistan, rape, as we know it in the United States, does not exist in the nomenclature. ${ }^{4}$

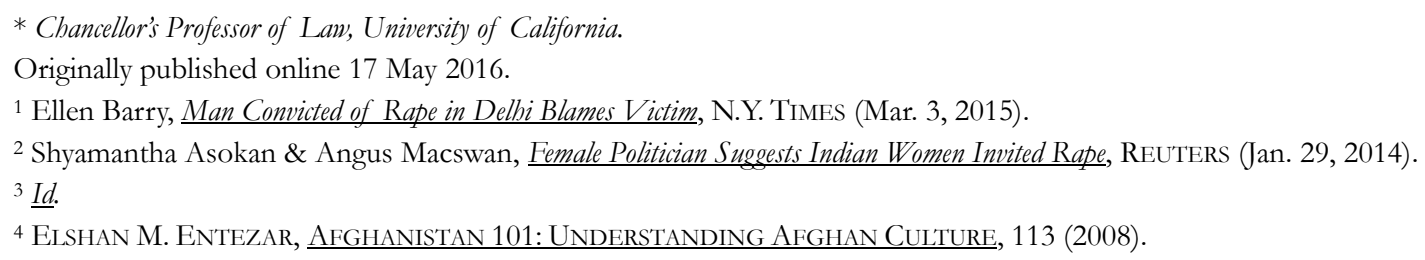


There are no words for "rape" either in Dari or in Pashto. The phrase "sexual attack" is used but not in the context of marital rape. To an Afghan raping one's wife is nonsense. Men do "it" whenever they feel like. It does not matter whether she likes it or not. If a wife went to court and complained, the judge would laugh and tell her not to make a fool of herself. For the same reason, Pasto and Dari have no word for "foreplay." This is because females are perceived as property and sex objects for the pleasure of men. ${ }^{5}$

Because the 2009 Afghan law on the elimination of violence against women does not clearly distinguish between rape and adultery, rape victims have actually been accused of and criminally charged for committing adultery. ${ }^{6}$ And despite efforts by civil society groups to "remove the concept of 'adultery' from the definition of rape," these notions of female (victims') culpability in sexual violence remain deeply embedded in cultural understandings. ${ }^{7}$ According to one newspaper report, authorities in Afghanistan charged a teen rape victim with "'adultery by force' - a 'crime' that carried a 12-year jail sentence." The sixteen-year-old victim became pregnant and gave birth in prison." According to Women for Afghan Women (WAW), 9 "over 90\% of the nearly 10,000 women and girls [they] have served since 2007 have been victims of domestic violence." Furthermore, WAW reports that their "clients have been raped, sold, beaten, starved and mutilated—primarily at the hands of a family member, or in some cases, multiple family members." ${ }^{10}$ More generally could be said about implicit bias and sex discriminations in judicial and legislative decision-making regarding rape. Consider the U.S. notorious role in ignoring child rape among its allies in Afghanistan. ${ }^{11}$

This essay urges a more probing look at not only how legal systems and the political actors who populate them contribute to shaming and stigmatization in cases of rape, which can chill victims' courage to report sexual violence, but also at how law itself creates legal and extralegal obstacles and problems for rape victims. Marital rape and sexual violence during war are two glaring examples. This essay turns to marital rape and argues that policies such as coverture, spousal immunity, and marital rape defense formed political and public policy foundations in law that continue to influence attitudes about sexual violence against married women committed by their spouses.

\section{Marital Rape}

In countries where contraceptives and abortions are banned or subjected to strict state scrutiny and oversight, the chilling consequences of rape lingers as lawmakers mandate that women and girls carry the pregnancies to term even when the health of the mother and fetus may be at risk. The consequences are dire. In 2015, an eleven-year-old victim of rape gave birth in Paraguay after government officials denied her the opportunity to terminate the pregnancy. ${ }^{12}$

\section{${ }^{5} \underline{I d}$.}

${ }^{6}$ Human Rights Watch, "We have the Promises of the World" - Women's Rights in Afghanistan 46-47 (2009); Tim Craig, An Afghan Girl's Story of Abduction and Rape Is Testing An Incoberent Justice System, WASHINGTON Post (March 10, 2016) (describing the horrific tale of a kidnapped and raped girl whose abuser forced her into marriage and was set free by law enforcement); Heather Saul, Afghan Woman Raped, Impregnated And Jailed For 'Adultery By Force' Marries Her Attacker, THE INDEPENDENT (April 8, 2015).

7 HuMAN RightS WATCH, “We HAVE THE PROMISES OF THE WORLD” - WOMEN's RIGHTS IN AFGHANISTAN 46-47 (2009).

8 Heather Saul, Afghan Woman Raped, Impregnated And Jailed For 'Adultery By Force' Marries Her Attacker, THE INDEPENDENT (April 8, 2015).

${ }^{9}$ WOMEN FOR AFGHAN WOMEN.

${ }^{10}$ Manizha Naderi, A Law That Would Permit Afghan Men To Hurt and Rape Female Relatives, The Guardian (Feb. 6, 2014).

11 Joseph Goldstein, U.S. Soldiers to Ignore Sexual Abuse of Boys by Afghan Allies, N.Y. Times (Sep. 20, 2015).

12 Rafael Romo, 11 Year Old Rape Victim Denied Abortion Gives Birth in Paraguay, CNN (Aug. 14, 2015). 
During that same period, government officials in Chile forced a ten-year-old rape victim to carry her pregnancy to term, despite local and international outcry. ${ }^{13}$ In that case, Amnesty International issued a statement comparing the state's response to legalized torture. ${ }^{14}$ Even more startling, officials prosecuted the girl's mother (for failure to protect the child) although it was she who first alerted law enforcement a year before about her husband's sexual abuse of their daughter. However, local police ignored her complaint. Frequently, law enforcement regards violence of this sort a private family matter. In other words, incest is the invisible crime. So too was marital rape and sadly in many parts of the world it continues to stigmatize and penalize women.

For centuries politicians and judges claimed that marital rape did not exist within law and as a matter of public policy could not occur. That is, it was impossible for a husband to rape his wife because they were "one" under the laws of God and man. Only recently governments moved to prosecute husbands who rapeprecisely because marriage served as a robust affirmative defense. For example, last year, Mandy Boardman, a business owner who lives in the United States came forward with a chilling account of her rape.$^{15}$ In that case, Boardman's husband, David Wise, drugged and raped her over a three-year period. On several occasions Wise filmed himself raping his wife while she lay unconscious. Despite being convicted of drugging and raping his wife, and a prosecutor's recommendation of a forty-year jail-term, Judge Kurt Eisgruber sentenced Boardman's ex-husband to home detention. Eisgruber warned Boardman that she needed to "forgive" her exhusband. Boardman's case raises important questions about the role of law in the prosecution of rape as well as how familiarity_or family—remains an embedded feature in the mitigation of sexual violence.

\section{Judicial Complicity and The Sanctity of Marriage: Ye Shall Be As One}

In 1736, Sir Matthew Hale's highly acclaimed treatise, Historia Placitorum Coronae, History of the Pleas of the Crown, maintained that it was impossible for a woman to be raped by her husband. Hale proclaimed that a "husband cannot be guilty of rape" because marriage conveys unconditional consent, whereby wives have entered a binding contract and "hath given up herself in this kind unto her husband, which she cannot retract." 16 No prior English common law articulated this standard, but Hale's new rule found broad support among parliamentarians and subsequently influenced legal developments in the British colonies and in the United States. Nearly every state legislature enacted laws that shielded husbands from criminal punishment for raping their wives (and sometimes even girlfriends). In 1993, North Carolina was the last state to rescind the marital rape exemption.

Conceptually and legally, wives' sexuality and sexual independence bundled within the ambit of property rights conferred to husbands. ${ }^{17}$ This common law standard became ensconced in law throughout the United States. As one court claimed, it "was a grave breach of marital duty" for wives to refuse intercourse with their husbands. ${ }^{18}$ According to the Supreme Court of Alabama, "a husband may enforce sexual connection ... and ... in the exercise of his marital right he cannot be guilty of the offense of rape." ${ }^{19}$ For centuries, courts

13 Polly Davis Doig, 10 Year Old Rape Victim Denied Abortion, USA ToDAY (May 5, 2015).

${ }^{14} \underline{I d}$.

15 Matt Pearce, No Prison Time for Indiana Man Convicted of Drugging, Raping Wife, L.A. Times (May 19, 2014).

16 Sir Matthew Hale, The History of the Pleas of the Crown 629 (1736).

17 See, e.g., Re Application of Kantrowitz, 24 Cal. App. 203 (1914); People v. Trumbley, 96 N.E. 573 (1911); State v. White, 44 Kan. $514(1890)$.

18 Anonymous, 206 Ala. 295, 299 (1921) (finding that a husband's abusive conduct, including demands for sex, refusing to allow his wife to work, and denying the wife means to pay for dental services did not justify her refusal to grant him sexual favors or withdrawal from the house).

${ }^{19} \underline{I d}$. (citing 13 R. C. L. pp. $987,988, \int$ 6). 
refused to recognize marital rape as a crime for which wives deserved any relief or safe harbor. That is, women lacked any right to refuse sexual intercourse and consent was irrelevant. ${ }^{20}$

Consider the 1857 case of Commonwealth v. Fogerty, ${ }^{21}$ which involved the brutal gang rape of a ten-year-old girl. In that case, the Supreme Court of Massachusetts found that the men who "ravished" the child could not plead exceptions. ${ }^{22}$ However, in very telling dicta, the court concluded by reminding the public, "[o]f course, it would always be competent for a party indicted to show, in defence [sic] of a charge of rape alleged to be actually committed by himself, that the woman on whom it was charged to have been committed was his wife." 23

A century later in People v. Henry, which involved a father's rape of his thirteen-year-old daughter, the court noted that it could not be disproved that the girl was not married ${ }^{24}$ to her father (or someone else), which would bar the state's prosecution of rape. ${ }^{25}$ The court chided the prosecution for assuming that a thirteenyear-old child is not married to anyone, including the father. ${ }^{26}$ The court remanded the case despite the daughter's pregnancy, childbirth, prior testimony, and the father's jailhouse confession to an officer:

"I was fondling her and she asked me what I was doing. Then I asked her didn't she want me to do that. She said she didn't know. Then I went ahead and had an act of sexual intercourse. I don't think that I got more than about one-quarter of an inch of my penis in her that time. The second and third acts were complete, and I experienced an orgasm on all three. It is possible that her child is mine but I'm not sure." Signed, Arvie D. Henry. 3:50, 1/28/54. Newton detectives, Officer Brantley and Hannibal. ${ }^{27}$

In State v. Paolella, a case involving the kidnapping — at gunpoint-and rape of an estranged wife, Connecticut courts acknowledged that "[c]ertainly there is ample evidence at this point for the court to find that the .. . basic elements of the rape have been proven." 28 However, the Supreme Court of Connecticut gave a strict reading to state legislation that exempted marital rape as a crime. The Court opined: "As noted . . . General Statutes $\int 53 a-65(2)$, which defines the sexual intercourse prohibited under $\iint 53 a-70(a)$ and $53 a-70 a(a)$, excludes married people. Under this statutory scheme, a defendant married to the alleged assault victim cannot be found guilty of violating those sexual assault statutes. ${ }^{29}$ "

In reviewing dozens of marital rape and incest cases involving husbands' sexual assaults against wives or daughters, clear patterns emerge. First, judges cling to legal formalism, frequently relying on prior case law

20 State v. Paolella, 210 Conn. 110 (1989) (referencing that under Conn. Gen. Stat. \53a-70(a) and 53a-70a(a), a finding by a trier of fact that the alleged offender and the victim were married exonerates the alleged offender, regardless of the proof of forcible sexual intercourse).

${ }^{21}$ Commonwealth v. Fogerty, 74 Mass. 489 (1857).

${ }^{22} \mathrm{Id}$.

${ }^{23} I d$. (emphasis added).

24 People v. Henry, 142 Cal. App. 2d 114, 120-21 (1965).

${ }^{25} \mathrm{Id}$.

${ }^{26} I d$. at 120-21 (finding, "in the present case, notwithstanding the evidence regarding the same surname, not having been married to defendant, not having been outside the county, and living at defendant's home, a marriage between Vickie and someone other than the defendant might have existed. There was not sufficient proof of the nonmarriage of Vickie to establish the nonmarriage element of the corpus delicti, and there was not a proper foundation for receiving the alleged confession in evidence").

${ }^{27} I d$. at 121.

${ }^{28}$ State v. Paolella, 210 Conn. 110, 116 (1989) (quoting the trial court, which clarified, "[t]he basis of the ruling as I indicated is the opinion of the Court that the spousal exemption is valid and the evidence indicates clearly . . . that these parties were still legally married on that day, and it is for that reason I am granting the Judgment of Acquittal as to these two counts.”).

${ }^{29} \underline{I d}$. at 123 . 
even when doing so conflicts with protecting basic human rights and sex equality. Second, courts avoid constitutional analysis, frequently failing to scrutinize the constitutionality of marital rape exemptions, thereby assuming their legitimacy and reifying the notions that a state possesses a legitimate interest in preserving familial harmony, that the least restrictive means of advancing that interest is by exempting husbands from criminal prosecution, and that a state's purported interest in marital harmony trumps a women's privacy and autonomy interests. Third, these cases reveal the high price of sex. That is, marital harmony was purchased at wives' expense. As one court noted, "marital exceptions may remove a substantial obstacle to the resumption of normal marital relations." 30 Finally, such cases emasculate juries.

In a rare exception, a Colorado court addressed the constitutionality of a marital rape exemption. In that case, the defendant (who raped a woman that was not his wife) claimed that the exception was unconstitutional in that it did not apply to cases such as his, thereby unequally protecting husbands who commit rapes, but not strangers and acquaintances. The court ruled that defendant lacked standing to bring such a claim, but nonetheless opined:

The legitimate state interest in encouraging the preservation of family relationships supports the distinction between assailants who are married to and living with their victims from those who are not. Second, the marital exception averts difficult emotional issues and problems of proof inherent in this sensitive area. Otherwise juries would be expected to fathom the intimate sexual feelings, frustrations, habits, and understandings unique to particular marital relationships. ${ }^{31}$

In crafting its opinion, the court dismissed the role and legitimacy of juries to hear troubling cases involving sex.

These cases shed light on courts' consistent participation in relegating wives' sexuality to the control and province of their husbands. ${ }^{32}$ Women lacked meaningful access to courts and therefore justice. ${ }^{33}$ As Robin West explains, "marital rape exemptions are strikingly easy to trace to misogynist roots, from Hale's infamous argument that a married woman is presumed to consent to all marital sex and, therefore, cannot be raped, to the common law's assumption that marriage results in the unification of husband and wife." 34 However, on close inspection, these cases also reveal as much about law's role in creating a climate in which marital rape flourished. For example, most states enacted marital rape exemptions. Ultimately, the history of marital rape in the United States underscores how women and their sexuality were deemed the property of their spouses, a principle enforced and protected by legislatures and courts.

\section{The Long Arch of Violence: Civil Sphere}

Sadly, courts treated physical violence in the home similarly to sexual violence. In cases of domestic violence, courts reasoned that preserving marital harmony was an important state goal in criminal as well as civil contexts. Thus, in cases of sexual and physical violence, intraspousal tort immunity shielded husbands from lawsuits filed by their wives. Even the Supreme Court warned that if Congress had intended to grant women

\footnotetext{
${ }^{30}$ People v. Brown, 632 P.2d 1025 (1981).

${ }^{31} \underline{I d}$.

32 Jill Elaine Hasday, Contest and Consent: A Legal History of Marital Rape, 88 CAL. L. Rev. 1373 (2000).

33 See, e.g., Catharine A. MacKinnon, Toward a Feminist Theory of the State (1989); Catharine A. MacKinnon, FemiNISM UNMODIFIED (1987).

${ }^{34}$ Robin West, Equality Theory, Marital Rape, and the Promise of the Fourteenth Amendment, 42 FLA. L. REv. 45, 64-65 (1990).
} 
permission to sue their husbands, thereby altering the common law governing husbands and wives, it would have articulated its intent with "irresistible clearness." 35

Thus, courts made clear the fruitlessness of women pursuing civil litigation against their husbands. In an effort to demonstrate its progressive leanings, a North Carolina court advised that its position had evolved: "we may assume that the old doctrine, that a husband had a right to whip his wife, provided he use a switch no larger than his thumb, is not law in North Carolina." 36 However, the court also ruled, "if no permanent injury has been inflicted, nor malice, cruelty nor dangerous violence shown by the husband, it is better to draw the curtain, shut out the public gaze, and leave the parties to forget and forgive." ${ }^{37}$ Courts throughout the United States adopted similar rationales, emphasizing the social importance of maintaining "domestic harmony" as a public policy value and goal. Courts in Maine articulated this goal slightly differently. In Abbott v. Abbott, ${ }^{38}$ the court denied Mrs. Abbott the opportunity to recover for injuries sustained after a brutal beating by her husband, which required hospitalization. In that case, the court emphasized the "husband and wife are one person." 39

According to courts, interspousal immunity doctrine, which emanated from coverture rules, fulfilled important social goals. Family immunity defenses advanced policy goals associated with the coverture model, in that U.S. tort doctrine protected husbands and fathers from tort liability and discouraged litigation from wives and children.

\section{Conclusion}

We ought to be concerned about the roots of marital rape and how this history may influence contemporary public policy and judicial opinions. As a public policy matter, courts declared it in society's interest that households reside in harmonious companionship, unimpaired by the tensions that could arise from litigation. In reality, courts preserved and legitimized systems of terror in U.S. households. Ultimately, courts prioritized the harmony and peace of husbands who raped and physically abused their wives. The terror experienced by wives under these conditions rarely —if ever-was taken into account.

35 Thompson v. Thompson, 218 U.S. 611, 618-19 (1910).

${ }^{36}$ State v. Oliver, 70 N.C. 60,62 (1874).

${ }^{37} \underline{I d}$.

38 Abbott v. Abbott, 67 Me. 304 (1877).

${ }^{39} \mathrm{Id}$. at 305. 